\title{
Winds of Change: Comparing the Early Phases of Constitutional Redrafting in Chile and Venezuela
}

\section{Carlos García Soto ${ }^{1} \cdot$ Miguel Ángel Martínez Meucci ${ }^{2} \cdot$ Raúl Sánchez Urribarrí $^{3}$}

Accepted: 8 October 2021 / Published online: 18 November 2021

(c) T.M.C. Asser Press 2021

\begin{abstract}
This article compares the early phases of the constitutional redrafting processes in Venezuela (1999) and currently in Chile (2021), seeking to identify key factors that help explain the radical constitutional-redrafting path that was followed in Venezuela, versus the more moderate, consensual and rule-bounded transformation underway in Chile. We pay particular attention to the presence of Hugo Chávez as leader of a populist project in Venezuela - an important factor absent in today's Chile-whilst also taking into account a host of other important considerations that situate these countries' diverse experiences in their respective socio-political contexts. These factors include the existence of unaddressed historical and social grievances leading to the reform; frustrated efforts at overhauling state institutions or the constitutional text; disparate institutional frameworks to channel reform demands, and different decisions made by the ruling political elites, among other considerations. Our goal is to provide a comprehensive and nuanced comparison that not only helps to understand each case better, but also to think critically about the complex reasons that lead to constitutional redrafting in troubled democracies, with a view to inform our debates on this topic beyond Chile and Venezuela.
\end{abstract}

Keywords Constitutional reform · Constitutional change · Constituent power · Venezuela $\cdot$ Chile

Raúl Sánchez Urribarrí

r.sanchezu@latrobe.edu.au

Carlos García Soto

cgarcia@uma.edu.ve

Miguel Ángel Martínez Meucci

miguel.martinez@uach.cl

1 Universidad Monteávila, Caracas, Venezuela

2 Universidad Austral de Chile, Puerto Montt, Chile

3 La Trobe University, Melbourne, VIC, Australia 


\section{The Importance of Comparing Venezuela (1999) and Chile (2021)}

A summary version of the conventional wisdom of the creation of the 1999 Venezuelan 'Bolivarian' Constitution would read like this: In 1998, Venezuela was a troubled democracy on the verge of change. Following years of economic decline, social strife and political conflict, an anti-system outsider candidate-Hugo Chávez Frías-was elected president. One of his main campaign proposals was to reform the system via a constituent assembly, a far-reaching constitutional change exercise that was supposed to lead to a more inclusive democracy and economic system.

Chávez pushed forward and led this change in 1999 via a contested, haphazard, one-sided process. Based on a particular interpretation of constituent power theory that, in Colón Ríos' words "resulted in the attribution of sovereign powers to a constituent assembly", 1 the 1961 Venezuelan constitutional norms for reforming the constitution were sidelined, allowing for the creation from scratch of a new constitution through a Constituent Assembly-the 1999 Constitution of the (now Bolivarian) Republic of Venezuela, also known as the Bolivarian Constitution. The abuse of the Assembly's powers eventually allowed for the displacement of the previous political elites and the evisceration of the regime's democratic institutions. ${ }^{2}$ Despite being portrayed as an inclusive and bottom-up democratic process, the text that resulted from that constitution-making exercise emerged as a Chavista political-legal instrument - a troubled and politicised framework that would do little to curb presidential power and, instead, would enable a populist, authoritarian leader to overhaul state institutions and dismantle Venezuela's democratic regime. ${ }^{3}$ Moreover, the replacement of the Venezuelan Constitution via constituent assembly as an essential part of Chávez's populist project served as inspiration to other left-wing, 'Pink Tide' populist governments to seek and achieve change via constituent assemblies, particularly in Bolivia (2007) and Ecuador (2008). ${ }^{4}$

Over 20 years later, the creation of the 1999 Venezuelan Constitution as part of the country's democratic backsliding process under Chavismo is often referred to as an emblematic example of what not to do in constitutional reform processes. It is approached with strong reservations, especially after the definitive collapse of Venezuelan democracy and the onset of Nicolás Maduro's autocratic regime following Chávez's death in 2013. For some, it is a reminder of the need to proceed with extra care with respect to any attempt to replace a constitution and not consider more moderate alternatives. For others who support constitutional replacement, the Venezuelan example is a cautionary tale with respect to embracing all-encompassing efforts to replace the constitution without agreed, pre-established limits on the

\footnotetext{
1 Colón Ríos (2020, p. 280). For more background on the history of constituent power, see Rubinelli (2020).

2 Landau (2013), Landau and Dixon (2015)

3 See works by Brewer Carías (2002, 2010), including his most recent work evoking the 1999 Constituent Assembly and its roots (2021).

${ }^{4}$ Bejarano and Segura (2020), see also Negretto (2018).
} 
reforming body's prerogatives and/or with adequate accountability mechanisms in place.

This is the case of the constitution-making process taking place in Chile, where Venezuela's fraught constitutional transformation process is recurringly invoked by critics and looms large in intellectual, scholar and public debates about the risks and possible pitfalls of constitutional change gone wrong. ${ }^{5}$ Moreover, the Venezuelan example is not only relevant as a scholarly or historical reference from afar. In recent years, hundreds of thousands of Venezuelan citizens have migrated to Chile, as part of a migration wave of millions of Venezuelans following the catastrophic collapse of the country's economy and the overall decay of state institutions and quality of life. As a result, Venezuela's democratic backsliding has ended up being a point of major political contention across the region, especially in those countries where Venezuelan citizens migrated. As Verdugo and Prieto Rudolphy have recently pointed out, ${ }^{6}$ the Venezuelan process has been openly averted in the Chilean case, aware of the risks that key political and legal choices entail to both the success of the assembly and to the subsequent prospects for democratic rule. However, as they have also highlighted in their contribution to this Special Issue, it still inspired the intellectual perspectives and political demands of a sector the Left in Chile, and the constitution is still in the making. So, its ongoing relevance cannot be quickly discarded.

Bearing in mind the importance of becoming familiar with the Venezuelan case, and to contribute to give nuance to comparisons between the two countries, we seek to put in perspective the Venezuelan experience, and extract lessons for the analysis and trajectory of Chile's current constitutional replacement efforts. There have been attempts to inform the debate and contrast the Chilean process to Venezuela's, ${ }^{7}$ but it is still important to compare the two processes as systematically as possible. The comparison would not only help to understand better each case, but also to help think critically about the role of socio-political conditions in the emergence and specific trajectory of constitutional reform efforts, with a view to inform our debates on this topic beyond Chile and Venezuela. ${ }^{8}$ In contrast to the Venezuelan example described above, the Chilean case has unfolded in a more consensual, inclusive, and regulated fashion than Venezuela's. These different trajectories are to a large degree related to Chávez's authoritarian leadership and populist discourse. Yet, the emergence of this leadership took place against the backdrop of specific socio-political conditions and historical context that are also critical to understand why the pathways and trajectories of constitutional redrafting in these countries diverge. ${ }^{9}$

Thus, in order to make sense of this variation, this article seeks to reflect on the following aspects of the constitution-making processes of these two countries: (i)

\footnotetext{
${ }^{5}$ For instance, see Aylwin (2019).

6 Verdugo and Prieto Rudolphy (2021).

7 For example, Vega (2020).

${ }^{8}$ On the importance of comparisons to advance conceptual debates and theory-building in Comparative Constitutionalism see Hirschl (2005), esp. p. 129 ss.; see also Hirschl (2015).

9 Bejarano and Segura (2008).
} 
The political and legal historical background to the transformation process; (ii) The key actors involved and the nature of the political crossroads/dilemmas faced (along with the reasons alleged for replacement); (iii) The key features of the political and legal choices made to transform the constitution. These aspects are essential to understand and evaluate the nature of these constitutional redrafting processes. ${ }^{10}$ To accomplish these goals, we first revisit and interrogate the conventional narrative about Venezuela's reform trajectory, by offering a critical summary of the key features of the political, social and legal context against which the constitution-making process of 1999 took place, i.e. a democratic liberal regime in crisis and the efforts carried out to overcome it-including proposals to reform or amend the 1961 Constitution employing the mechanisms established in this text. Next, we describe the key causal mechanisms behind the constitutional reform juncture of 1998-1999, looking in particular at the different dimensions of the actually existing 'crisis' of the 1990s, the arrival of Hugo Chávez in the political scene and the propuesta constituyente, i.e. his proposal to overhaul the 1961 Constitution. Next, we provide a brief summary of the creation, election and installation of the controversial 1999 Constituent Assembly, including the constitutional and political debates took place in relation to its creation, the judicialization of the conflict surrounding the reform proposal, and the subsequent election of the Constituent Assembly. Following this brief summary, we proceed to compare this experience to Chile's, focusing on the three aspects and extracting lessons about the similarities and differences between the two processes.

This allows us to develop a better understanding of the disparate trajectories of constitutional reform in both countries to date, and a good foundation for future comparative analyses between their impact on democratic rule in the future. It also gives us novel perspectives to (re)think what went wrong in Venezuela, particularly what allowed for such a radical constitutional transformation to take place.

\section{Venezuela: Crisis and Ideas of Reform before the 1999 Constituent Assembly}

Venezuela's political and economic crisis in the late 1990s-which resulted in Chávez's election and the 1999 Constituent Assembly-was the final stage of the economic, social and political turmoil that Venezuela endured during the 1980s/ early 1990s. ${ }^{11}$ In this context, talks of state reform and socio-political change were not uncommon. This included the possibility of modifying the constitution or otherwise making profound legislative change. Several academics, intellectuals and politicians had raised concerns about the country's political system increasing dysfunctionality, its lack of legitimacy, and had begun arguing for reform in a variety

\footnotetext{
10 See essays in Negretto (2020), highlighting the importance of paying attention to the country's historical trajectory, socio-political context and specific details of case studies when making sense of constitution-making processes and their contribution to sustaining democratic rule.

11 See Brewer Carías (1998).
} 
of ways. ${ }^{12}$ Moreover, these ideas also emerged in a regional/global context that witnessed the ushering in of the 'third wave of democracy', and the increasing push for political and state reform across Latin America and vast swaths of the Global South in the 1990s, sponsored by international organisations, international financial institutions and a growing network of civic society organisations and transnational networks. ${ }^{13}$ These were important antecedents of the constitutional reform mindset that would gain currency towards the end of the 1990s. ${ }^{14}$

The earlier demands for reform that took place in the 1980s were not entirely unheeded and led to efforts to overhaul Venezuela's institutional framework that were important antecedents of the country's eventual constitutional redrafting in 1999. This includes two noteworthy initiatives; on one hand, in the mid-1980s, the Jaime Lusinchi's social-democratic Democratic Action (AD) government established a Presidential Commission to document, evaluate and draft a series of proposals to overhaul the State-the Comisión para la Reforma del Estado, i.e. 'Commission for the Reform of the State' (best known by its acronym COPRE). ${ }^{15}$ Later, following increasing social strife and political instability during the second mandate of Carlos Andrés Pérez (1989-1993, also from AD) the Venezuelan federal legislative branch (Congress) created a Presidential Commission to study different proposals to reform the state, including an initiative to reform the 1961 Constitution. $^{16}$ Both initiatives deserve additional consideration, as they had a significant influence in the perception of the prospects and possibilities for reform amongst opposition politicians and a broader set of actors.

With respect to the COPRE, the Commission was in charge of studying policy and government areas where the institutional framework or goals of the 1961 Constitution had not been accomplished. This body became a liaison between the state and a variety of civil society organizations that were being formed in response to the system's deficiencies and challenges - such as increasing corruption, mismanagement, rising crime, excessive centralisation and an unresponsive bureaucracy — and which typically lacked influence on the country's two main political parties, AD and COPEI. ${ }^{17}$ The Commission was led by renowned academics and political leaders who, in systematic and rigorous fashion, offered diagnostics and tentative proposals

\footnotetext{
12 Hernández Muñoz (2008, p. 200).

13 Ungar (2002); on the importance of networks see Keck and Sikkink (1998). The state and civic society reforms that took place in Venezuela during that time were eventually eclipsed by the sweeping reform processes ushered in by the Bolivarian Revolution. Accordingly, scholars have tended to neglect this important phase, take stock of its success or failures and their influence (and even persistence) within eventual reform efforts carried out under the Chávez administration.

14 A very interesting part of writing this article was our discussions about our own personal experiences on this topic and reminiscing about the relevance of these ideas for their undergraduate studies in Law and Political Science in Caracas during the 1990s/early 2000s. We recalled how ideas about state reform past or present influenced our learning of Public Law subjects-including the possibility of constitutional amendments or reform within the scope of the 1961 Constitution-, and how these ideas were perceived as vital aspects of an overarching debate on revitalising democracy in Venezuela.

15 Levine (1998, p. 187).

16 Combellas (1993).

17 Garcia Guadilla and Roa (1996).
} 
that transcended the politics of the day, arguing explicitly for institutional reform across a variety of areas. These calls for reform were widely publicized and discussed in political and academic circles, from university classrooms to research projects of different sorts.

However, abated by growing problems and demands from different sectors, and lacking the leadership to make some of these reforms reality, no consensus emerged within the country's leading elites to enact those proposals. An important exception became the adoption of popular, direct elections of regional and local political authorities via legislation in 1989 and the devolution of several federal powers to the regions and municipalities that same year. ${ }^{18}$ These reforms were quasi-constitutional in nature and significance and had major effects in the country's political life, including the emergence of new leadership at the subnational level independent from the leadership of the major political parties. ${ }^{19}$ These reforms also encouraged reform-minded intellectuals to push for further, more aggressive institutional experimentation, and to encourage academic work about options for reforming the system. Finally, some of the work developed by COPRE and embraced by this wide-range group of actors would be well-received by an ever-mobilised civil society, which would end up becoming increasingly organised in the following decade.

The call for reforms became even stronger during the 1990s, especially after the 1989 riots in Caracas known as Caracazo. ${ }^{20}$ These riots were unprecedented, sudden, and tragic, resulting in a still-contested number of deaths (in the hundreds or even thousands), widespread loss of property and a resulting loss of sense of political stability. ${ }^{21}$ In the context of rising political turmoil, the options of constitutional reform and a far-reaching constituent assembly came to the fore. Consultations for reform took place between June 1989 and 1992 by a congressional Bicameral Committee presided by the ex-president Rafael Caldera. At the beginning, the dominant view was to propose minor modifications via an amendment process ('enmienda', as defined in the 1961 Constitution), and achieve key institutional transformations via law reform. ${ }^{22}$ Interestingly, these debates included the possibility of establishing a provision in the Constitution to hold a constituent assembly. ${ }^{23}$ Yet, these early discussions did not count with the support of the political class, the president, leading media outlets and other key actors, especially after Hugo Chávez's unsuccessful military coup on February 4, 1992. This coup and its follow-up military uprising in November the same year fuelled an overall sense of social instability and regime vulnerability that would persist throughout the 1990s.

\footnotetext{
18 Cuñarro Conde (2009).

19 Penfold-Becerra (2004).

20 Kornblith (1991).

21 López Maya (2003).

22 The 1961 Venezuelan Constitution established only two mechanisms for change: Amendments and Reform. The reform option involved a complex multi-step process and required a referendum. Whilst there had been two amendments in the constitution 3-decade long history, it had never been reformed. Also, as we discuss below, the 1961 Constitution did not contemplate a provision for a constituent assembly. See Braver (2016), Brewer Carías (2002).

23 Combellas (1993).
} 
Thus, the attempted reform process 'failed to open new channels between civil society and the state', ${ }^{24}$ and was received by some quartiers as a deliberately failed effort or a ploy to prevent change. ${ }^{25}$ Although in vain, these initiatives reflected the growing interest in reform at the elite and public opinion level and included ideas that would later inform part of the changes adopted by the 1999 Chavista constituent assembly. Moreover, they increased the perception among part of the country's political and intellectual elites that the system's key actors would not be invested in reform and that a total, radical change was needed. In fact, some intellectuals began arguing for a constituyente process more explicitly. ${ }^{26}$ In 1991, a group of intellectuals known as Frente Patriotico ('Patriotic Front') openly called for a constituent assembly. ${ }^{27}$ Soon thereafter, following Chávez's 1992 aborted coup other actors joined calls for broad constitutional reform. ${ }^{28}$ This group included the movement affiliated with Chávez and several political leaders. This also became the favourite option of several civil society organizations, on the assumption that Congress lacked legitimacy to spearhead the reform process. ${ }^{29}$ The varied group of civil society organizations included groups that would eventually actively support the 1999 constitutional changes, submit proposals to the Constituent Assembly, and actively work towards implementing the new Constitution's rights catalog—bearing in mind that, at that time, civil society movements differed in their preferences and some openly rebuked the possibility of a Constituyente. ${ }^{30}$

These early calls for a constituent assembly became moot after 1993-at least for some time. President Pérez was removed in mid-1993, and subsequently Caldera was elected president for the 1994-1999 period. Although Caldera showed nominal support for reform early in 1994, renewed—and eventually successful—explicit calls and efforts to reform the constitution did not took off until Chávez embraced the constituent assembly as the main proposal during the runup to 1998 presidential election, in the context of a complex crisis. Yet, by the time Chávez arrived and articulated the constituent assembly as a proposal, there were already many who were ready to see it as a viable avenue for reform. What they might have not been convinced of, though, was of the need to tie that process to the complete overhaul of the political system, which ended up being an important consequence of the constitution-making process. ${ }^{31}$

\footnotetext{
${ }^{24}$ Garcia-Guadilla and Roa, p. 87.

25 Gabaldón Domínguez (1992).

26 See Brewer Carías (2002).

27 Frente Patriótico (1991).

28 Ayala Corao and Casal (2008).

29 Garcia Guadilla and Roa.

30 The participation of civic society in the 1999 Constituent Assembly, and the extent to which prior processes of civil society activism resulted in their participation in the constitution-making process and beyond in the Venezuelan context, is a very important topic that requires additional empirical inquiry in line with recent scholarly developments in comparative analysis (e.g., see Negretto 2020 and Hudson 2021).

31 Chávez made a big effort to tie discursively the need for takeover of existing institutions to the constitutional project's success, and ongoing successes at the ballot box in 1999 and 2000 reaffirmed his plans. Yet, this was a major grievance for the political opposition, and an important source of hesitance
} 


\section{Chávez's Election and the Creation of the 1999 Constituent Assembly}

In 1998 Hugo Chávez's election upset Venezuela's political landscape overnight and heralded major political and institutional transformations. Elected with $56.2 \%$ of the popular vote, Chávez argued that the constituent assembly would be an ideal mechanism to enhance popular representation, carry out a complete overhaul of state institutions and displace AD and COPEI's corrupt political elites-all at once. He portrayed the December 1998 election as a transformative milestone towards an inclusive participatory democracy that would address major socio-economic exclusion and provide "a foundation of real power for an irrevocable and permanent revolution". ${ }^{32}$ In order to create the text and break with the 1961 constitutional order, Chávez referred to the idea of the people as true sovereign and legitimate source of 'constituent power'. ${ }^{33}$ Moreover, he framed the need for change as a key part of his populist discourse-with the new Constitution, there would be revenge against the old elites and a legitimate vehicle to enable and enact the people's will. This was directly linked to an overarching populist discourse that demanded deep, ongoing transformations and where institutional or legal restrictions would come second to the 'voice of the people' and Chávez's will as their legitimate leader. ${ }^{34}$

Shortly after his election, in January 1999, the Supreme Court paved the way to consult the people directly via referendum to approve convoking a constituent assembly, ${ }^{35}$ initiating a process of judicial intervention that sought to establish a constitutional and jurisdictional foundation for the constitution-making process to come. ${ }^{36}$ This position was directly at odds with intellectual and opposition politicians who pushed for the need to reform the constitution in order to allow for a constituent assembly. ${ }^{37}$ On February 2, 1999, the same day of his inauguration, Chávez issued a decree to call for a referendum 'not only to elaborate a new Constitution, but to function as a delegate of the people's sovereignty' and thus dismantle the current political structure. ${ }^{38}$ Chávez also requested that in the same referendum voters authorized him to define the terms of the Assembly's election, organization and authority. On March 10, 1999, the President issued a decree establishing the basis for the referendum, which would take place on April 25, 1999. This led to subsequent litigation before the Supreme Court, which largely confirmed the referendum's legality, but modified one of the premises of the decree that asserted the constituent

\footnotetext{
Footnote 31 (continued)

about the project for people who would eventually stop supporting the Chavista project (or denounce it altogether).

32 Rey (2007, p. 308).

33 Colón Ríos (2011).

${ }^{34}$ For a discussion on populism in Venezuela under Chávez, see Hawkins (2010); for its persistent authoritarian character and effects on state and society after Chavismo, see López Maya (2018).

35 See Aveledo (2001).

36 Braver (2016).

37 Brewer Carías (2021).

38 Rey, p. 309.
} 
('originaria') character of the Assembly. On that date, about $88 \%$ of voters approve calling a constituent assembly, and close to $82 \%$ approved the guidelines proposed for the assembly by the executive - figures that are less impressive if we consider that less than $40 \%$ of the electorate voted in such a high-stakes event in a highly polarised political environment.

Subsequently, the election of the Constituent Assembly took place 3 months later, on July 25, 1999. Although the election was supposed to be nominal and de-emphasize the role of political parties (candidates could run sponsored by parties, civil society organizations and even on their own initiative), the ruling 'Polo Patriótico' coalition campaigned and actively assisted to vote for lists ('kinos') of candidates competing against a fragmented opposition landscape. With about $46 \%$ electoral participation, Chávez's candidates ended up counting with a whopping 124 seats from the 131 available (despite having received only $62.1 \%$ of the votes). ${ }^{39}$ This is how the Bolivarian constitutional project excluded the participation of a large part of the electorate and led to an extremely biased constituent body that failed to properly represent the varied forces that were pressing for constitutional change.

On August 3, 1999, the Constituent Assembly was established, and immediately proceeded to declare that it would act on representation of the people and as constituent power, and therefore authorized to reorganize the state, create a new juridical order, and even restrict or cease the activities of the existing branches of power. ${ }^{40}$ This effectively placed the acts of the Constituent Assembly above the 1961 Constitution, which would only remain enforceable to the extent that it did not contradict the Constituent Assembly's acts and decisions. As Brewer-Carías highlights, the most controversial of these decisions was the August 12, 1999 Decree that ordered the reorganization of the branches of power and reasserted the Assembly's prerogative to intervene the existing constitutional authorities. This was followed by a decree a week later, on August 19, 1999, that declared the judicial branch 'in emergency', ordered its restructuring and established a new administration for the judiciary; and subsequent decrees on August 25 and August 30, 1999, that would intervene and cease the operation of the Congress, replacing it for an ad hoc Legislative Commission or 'Congresillo' designated with members of the Assembly. ${ }^{41}$

Chávez was supposed to promote a 'democratic' constitution-making process, with active participation of civic society and a wide range of political forces. As we can see, this is not what happened. As has been widely documented, the President and his close enclave ended up exercising an overwhelming dominance in the constitution-making process. This also explained how the constitution would be made in about 3 months, and subject to referendum on December 15, 1999 with almost no deliberation or public discussion. ${ }^{42}$ The work of the Constituent Assembly was done

\footnotetext{
39 Garcia Guadilla and Hurtado (2000).

40 Brewer Carías (2010).

41 As explained in Sánchez Urribarrí (2011), a majority of members of the Supreme Court strategically sided with Chavismo and decided to cooperate with the intervention of the judiciary, by way of a special agreement (Acuerdo) on August 24, 1999, and later refused to declare the unconstitutionality or illegality of the Assembly's acts (Sánchez Urribarrí 2011).

42 The final constitutional text was shared just a few days before the Referendum took place.
} 
in expedite fashion, with the whole elaboration of the Constitution taking little more than 3 months and subjecting the constitutional text to referendum on December 15 , 1999. The final constitutional text was only shared with the electorate 2 days before the referendum. The Constitution was approved with about $72 \%$ of the popular vote, but with relatively low levels of participation and in a highly polarised political environment. ${ }^{43}$ This initial polarisation would continue-and dramatically increase-in the years to come, with the constitutional project's implementation being inextricably tied to Hugo Chávez's discourse, preferences, and policy initiatives.

\section{Comparing Venezuela and Chile's Reform Trajectories}

Having foregrounded the key features of the trajectory of the constitutional reform process in Venezuela prior to the installation of the Constituent Assembly, we now proceed to compare three key aspects of this trajectory-the socio-political context prior to the constitution-making process; the political crossroads and contestation that led to the adoption of the reform and the key choices made regarding the constitution-making body. Whilst there is a wider range of aspects that could be included in a comparison, we limited ourselves to key variables that help explain subsequent constitutional reform processes: Perceived historical grievances in the country's (recent) past; major efforts to reform state institutions and/or the constitution; a context of socio-political crisis; the role of the president and other key elite actors; the existence of influential examples from abroad to support (or discourage) constitutional redrafting efforts; the existence of a legal pathway or framework to reform the constitution, particularly to invoke a constituent assembly; the level of disagreement/consensus between political players (polarisation); and key features of the election and design process prior to the installation of the Assembly.

As we can see below, the two processes are very different, although there are several important similarities that are worth singling out and commenting on. As we compare these different aspects, we reflect on the relevance of the socio-political background, the importance of Chávez in the Venezuelan case as a pivotal actor in the reform process, and the participation of other actors in the diverse trajectories of reform that unfolded in Chile and Venezuela (see Table 1).

\subsection{Socio-Political Background}

As discussed above, in Venezuela the 1961 constitutional order and the democratic system built on its premises entered a fraught, critical stage in the 1980s/1990s for a variety of reasons. This multifaceted crisis did not indict the origin of the political system, nor it effectively challenged the premise of constitutional democracy as a form of government. ${ }^{44}$ However, over time the crisis' weight and responsibility fell

\footnotetext{
${ }^{43}$ Less than half of the electorate (i.e., $44.38 \%$ ).

44 Bearing in mind that people's disillusion with the performance of the AD-COPEI regime, nostalgic accounts of more effective governance under dictatorship in the distant past, and the arrival of Chávez (a military lieutenant) in the scene did affect democratic legitimacy to a large degree.
} 


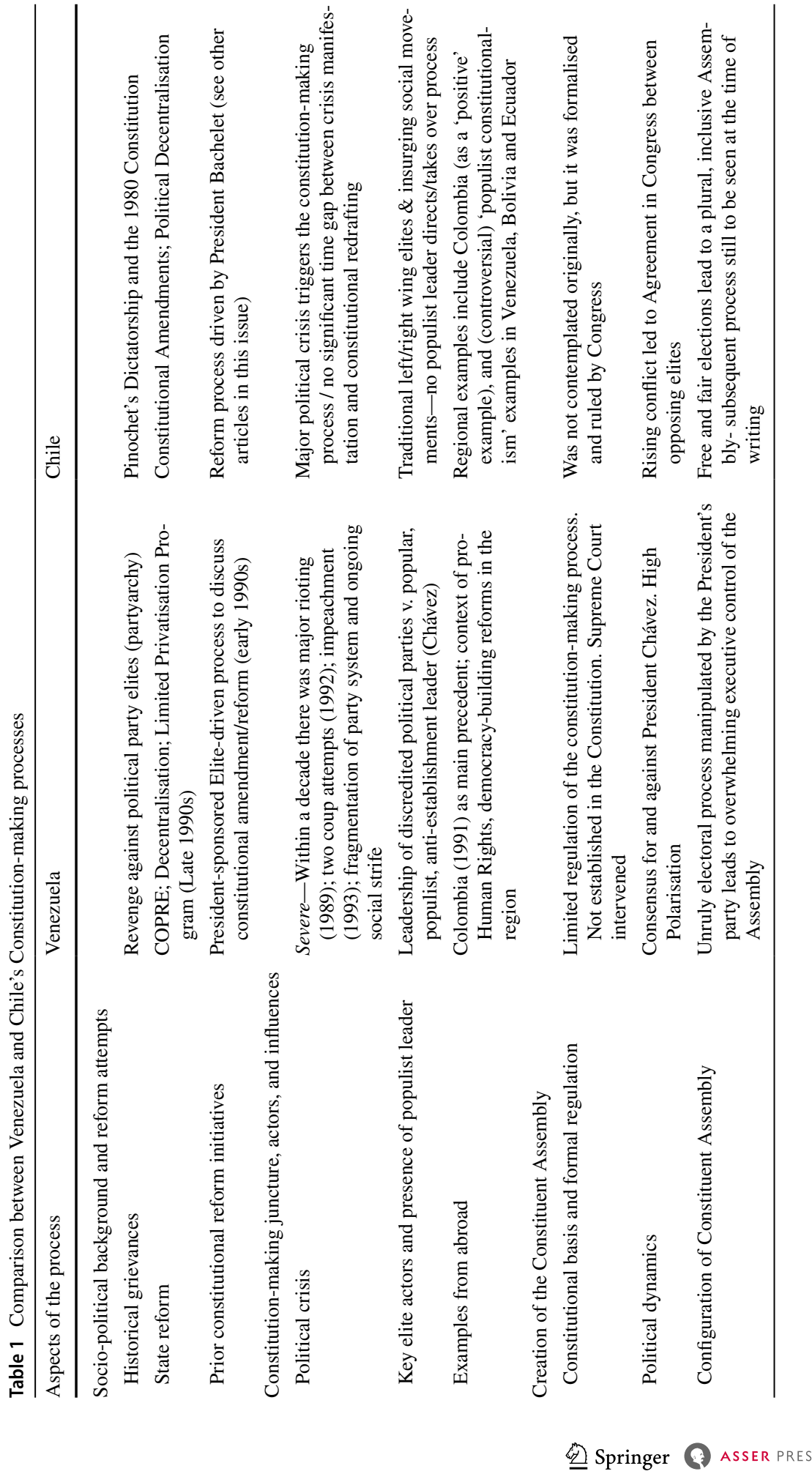


directly on the shoulders of the system's key political parties, who were blamed for the crisis and portrayed as an obstacle for reform. This was an argument that Chávez promoted very effectively, not only to win the 1998 election but also to reform the system and, most importantly, use the 1999 Constituent Assembly as an avenue to pursue and achieve regime change. In comparison, the constitutional redrafting process in Chile had a very different background. Whilst Venezuela's crisis went on for almost 2 decades within a faltering democratic regime that had a democratic constitutional order-1961's_-as a backdrop, Chile's recent democratic experience took place within the context of the 1980 Constitution, designed and approved under Augusto Pinochet's dictatorship and perceived as such—despite the country's successful democratic transition and consolidation. The 1980 Constitution had been denounced ever since as an authoritarian constitution, and the proposal of a constituent assembly had been gravitating ever since as an aspiration, which only became stronger after the transition to democracy that took place following Pinochet's defeat in the 1988 national plebiscite. Whilst the constitutional amendments of 1989 and 2005 helped to dismantle large swaths of the system's infamous 'authoritarian enclaves', there were strong criticisms against the 'subsidiary principle' (which leaves great space to the market and civil society, while reserving only key responsibilities for the State). ${ }^{45}$ More importantly, the 1980 Constitution remains a symbol of authoritarian rule, i.e. the 'dictatorship's constitution' (la constitución de la dictadura).

There are also important similarities and differences between the two processes concerning past institutional reform attempts. On one hand, the radical transformation that took place via the 1999 Venezuelan Constitution was, to a large degree, the result of the frustrations with the lack of timely changes to the system; the lack of effective mechanisms to deal with a sclerotic, corrupt bureaucracy, and the mounting resistance to the haphazard economic liberalisation process the country had just experienced in the 1990s. On the other hand, in Chile, the lack of effective, timely and adequate state reforms is also a critical factor to consider when making sense of the pathway to constitutional reform. However, the frustration with reform and the effect this had on the eventual rise of discontent, protests and collective action that resulted in constitutional reform is different from Venezuela's. In Chile, the liberalisation of the economy began taking place well before the advent of democracy, during the country's authoritarian phase, trusting key state and social services in the hands of the private sector-including education, healthcare, and social security among others. Several of these policies have experienced very limited changes during the democratic period, despite growing popular discontent and strong differences between right and left about their relative success and significance. ${ }^{46}$ The

\footnotetext{
45 See Garreton (2003) and Siavelis (2009). More recently, see García and Verdugo (2020).

46 This is different from Venezuela's discontent against Neoliberalism, since this project was less successful and more limited in that country. One could say that in Venezuela the citizens' grievance was, to some degree, the political elites' betrayal to the country's socio-political model that had emerged in the 1961 Constitution, combined with widespread rejection against Neoliberal attempts to overhaul it.
} 
claims for reform take place, to a large degree, to address this ongoing discontent, and directly inform the constitutional redrafting exercise.

Moreover-and in response to growing demands for state reform-there has been a substantial effort in recent years in Chile to decentralise the state, including the adoption of subnational elections of regional governors in May 2021. However, some might say this has been 'too little, too late', and that pending claims for a renewed distribution of power are still in need to be addressed. On the other hand, as we discussed above, Venezuela's experience with decentralisation throughout the 1990s was uneven, and the 1999 Constitution would reflect a clash between the government and political parties' intent to centralise and enhance top-down control, versus a nominal commitment to community-driven, participatory democracy. Thus, whilst in Venezuela and Chile the constitutional redrafting process would address frustrations with their respective experiences of state reform, the backgrounds and relative contribution of those frustrations to the specific constitution-making trajectories that eventually took place are significantly different. Further research could elaborate on what ways these two processes differ and explore further the relationship between state reform and constitutional redrafting.

Finally, with respect to the relevance of previous constitutional reform efforts, we see that in both cases previous (unsuccessful) attempts are related to subsequent constitutional trajectories. However, once again, this happened in different ways. Venezuela's proposals for constitutional reform in the years prior to Chávez's arrival in power did not eventuate in concrete processes. Whilst there were important reform efforts and proposals that hailed back to the mid-1980s, and explicit efforts at a later stage to study how to update the constitutional text, these efforts were unsuccessful and failed to gain traction, with important consequences for the eventual prospects of radical reform. Conversely, Chile did have a significant effort at reforming the Constitution during the second administration of President Michelle Bachelet (2014-2018). However, as discussed elsewhere in this issue, the reform process was marred by lack of political consensus, a failure to properly channel popular participation, and the opposition of key political sectors (especially right-wing parties). ${ }^{47}$ As a result, the reform never came into fruition. To a large degree, the current reform process has grappled with this experience and has sought to avoid the pitfalls of the previous attempt.

\subsection{Constitution-Making Juncture, Actors and Influences}

Both the Venezuelan 1999 Constitution and the forthcoming Chilean constitution can be considered the result of processes involving major political conflict and civic strife. In both cases, an estallido social ('social outburst') and ongoing trajectories of social contention can be identified, although they unfolded in different ways. On one hand, in Venezuela, the political protests of 1989 did away with the country's

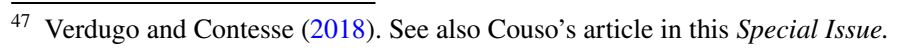


'illusion of harmony', ${ }^{48}$ and triggered a decade-long process of regime deterioration that ended with Chávez's transformative election in 1998. In Chile there is also an important connection to be explored between social strife/contention and constitutional change. The sudden, surprising surge of strong protests in 2019 led to the current constitutional reform process as main outcome. Like in Venezuela, they were controversial, sometimes violent, and reflected the growing discontent of vast sectors of the population unhappy with the existing socio-political system.

However, there are important differences in the way the protests related to the constitution-making projects it elicited. The Venezuelan experience with social strife involving the dramatic episode of El Caracazo riots in February 1989, the 1992 coups and the defenestration of President Perez did not result in a consensual approach to address the crisis. As discussed in other articles in this issue, the system languished for years. Instead, Chile's constitution-making process was triggered by the protests and the Piñera Government's inability to lead an official response and control the situation in a way that was legitimate, inclusive and effective. Congress took the initiative given Piñera's inaction and declining political support, leading to the "Agreement for Social Peace and a New Constitution" ('Acuerdo por la Paz. Social y la Nueva Constitución') signed by a wide roster of the system's leading and most representative political parties. This included representatives from the rightwing parties, who saw in the agreement a mechanism to reduce social tensions and help bring to an end weeks of political conflict. Thus, with varied enthusiasm, the agreement represented a consensual effort by a range of political forces to reconstitute the state, and to doing so via a constitutional, legal pathway. ${ }^{49}$

This difference speaks to a related important distinction between the two cases, with respect to the way the leading political and business elites in each regime reacted to constitution-reform pressures, and the way in which these elite actors interacted with one another. Despite the increasingly tense political situation in Chile in the last years, and the evident tensions and divisions between left- and right-wing political groups, the country's elites were able to channel the process through existing institutional mechanisms. This, despite facing the challenge of reckoning with, and including, a wide range of progressive forces in the left that challenged the role and control exerted by the country's leading political parties. ${ }^{50}$ Facing increasing social strife and despite reservations, the country's predominant right-wing parties and their affiliated business, industrial sectors and groups engaged with the process that led to the creation of the constitutional convention - at least to some degree. ${ }^{51}$

Although the demise of the traditional political party system and the dwindling influence of the previous political elites has echoes of what happened in Venezuela, the constitution-making process in Venezuela was very different. The salient

\footnotetext{
48 As denounced by Naím and Piñango (1985).

49 See Sect. 4.3 below.

${ }^{50}$ Including centre-left parties, ended up in the awkward position of backing protests that were directed to a regime where they were a vital participant.

51 Although, as we know, they eventually failed to secure a significant presence in the Convention, a topic that can be better discussed in separate analysis.
} 
democratic regime's actors had little to no participation in the constitution-making process, were strongly opposed to it and were eventually sidelined via an electoral process designed to overrepresent Chavismo's political majority. Moreover, whilst the social and political forces that Chávez managed to group under his political movement's umbrella included several political parties, politicians, business and social leaders with a presence/role in the previous regime, his project was dominated by new faces and, most importantly, by his overwhelming presence and leadership. More importantly, from the beginning the constitutional reform process in Venezuela was portrayed, defined and organised as an effort to displace the country's previous ruling elites.

Hence, a key difference between the two processes is the presence in Venezuela (and absence in Chile) of a charismatic leader who led the entire constitution-making process. Coming from the army and making himself known during the failed military coup of February 1992, Chávez became the symbol of radical change and presented himself as the incarnation of constituent power and sole representative of the nation. His presidential campaign in 1998 revolved around the fight against corruption and the holding of a constituent assembly to "re-found the republic". On several occasions he decided important issues in the Constituent Assembly, even if he was not himself a deputy of this body. On the contrary, in Chile the constituent process emerged as a collective demand, driven by political and social forces so diverse that the building of a consensus between them is hard to achieve. Whilst there was an agreement to proceed to reform the constitution, the actual decisions regarding the content of the constitution and even the dynamics of the Constitutional Convention are complex. They are not pushed or driven by a single leader (as was the case in Venezuela), and require democratic debate and deliberation.

Whilst this is normatively desirable for purposes of democratic inclusion and legitimacy, it also creates tensions that are not easy to resolve-and which might enable some members of the Convention and other actors to advocate for solutions that facilitate a majoritarian approach. Some constituents are even trying to change the agreed rule of $2 / 3$ approval for $3 / 5$, something feared by those who see in this process the possibility of a historical revenge similar to the one that took place in Venezuela. ${ }^{52}$ It may be said that Pinochet's figure and legacy represent the "antileader" of this process, as many expected changes in the constitution seem driven by the purpose to overcome the legacy of his authoritarian regime. ${ }^{53}$ More importantly, the forthcoming presidential election in Chile, to be held during the initiallyconceived life time of the Constitutional Convention (June 2021-June 2022) creates the possibility for a president who could exert an important influence in the constitution-making process. Thus, although the emergence of a figure as charismatic and central to the process as Chávez seems unlikely, the idea of having a "constituent

\footnotetext{
52 See https://www.publimetro.cl/cl/noticias/2021/09/20/convencion-modificar-quorum.html (Accessed on September 22, 2021).

53 Comments along these lines are still commonplace in the media. For example, see https://www.elsal todiario.com/mapas/ignacio-silva-nueva-constitucion-desamarrara-definitivamente-general-pinochet (Accessed on September 23, 2021).
} 
president" who could exert an important influence during the process should not yet be ruled out.

As a last point in this section, in terms of noteworthy influences, it is important to notice that the constitution-making process in late 1990s Venezuela did not have a wide scope of well-documented, influential examples to cite and rely on as paradigms to carry out reform, or on how to create legitimate/legal avenues to redraft the constitution. The (successful) example of the 1991 Colombian Constitutional Assembly was widely considered an example to consider, but it was already distant timewise, and had taken place in a socio-political context very different to Venezuela's. The 1999 Bolivarian Constitution was pushed by a newly elected populist, transformative President who used the opportunity as part of an overall regime change strategy, as opposed to the approach that had prevailed in Colombia. Instead, the 1999 Venezuelan Constituent Assembly_and the Bolivian and Ecuadorian examples that followed few years later-were all-encompassing exercises that took place in tandem with populist leadership and to broader socio-political transformation processes under the moniker of ' 21 st Century Socialism' (as part of the 'Pink Tide' wave of left-wing populist governments elected in the 2000s). These projects have helped shape political and legal debates in Chile, with a wide range of views expressed in recent years with respect to their nature, consequences, and relevance. ${ }^{54}$

\subsection{Creation and Configuration of the Assembly/Convention}

The difference in terms of the creation, election and subsequent configuration of the Assembly is, so far, notable. The main reason for this distinction lies on the regulation of the constitutional process - which has been a distinctive feature of the Chilean constitution but was absent and ad-hoc in the Venezuelan case. In the Venezuelan case, one of the major issues prior to the constituent process was precisely that the convocation of a constitutional redrafting process through a Constituent Assembly was neither foreseen nor regulated in the 1961 Constitution. Academics and intellectuals warned about the need for Congress to establish rules to repeal the 1961 Constitution through a constituent process, so that a National Constituent Assembly could be convened and create a new constitution to replace the 1961's text. ${ }^{55}$ These warnings were not heeded, and Congress refrained from reforming the Constitution to include the National Constituent Assembly. Hence, when Chávez was elected President, the path of creating a National Constituent Assembly was not available in the Constitution of 1961. As we discussed above, Chávez and his supporters addressed this problem by relying on Supreme Court's rulings that allowed him to issue a decree to convoke the Assembly, sidelining the need to regulate the process and place specific boundaries to the Assembly's organisation and actions. This situation led to two major consequences: On the one hand, the constituent process was convened and functioned without major internal operating rules and, on the

\footnotetext{
54 Barrientos (2014), Negretto (2015).

55 Brewer Carías (2002).
} 
other hand, that in practice it was very difficult for any citizen or civil society organizations to bring judicial cases against the constituent process once it was underway.

On the other hand, in Chile, the 1980 Constitution or its multiple amendments under democracy did not establish a specific mechanism to replace the Constitution via a constituent assembly or convention. This lack of clarity allowed for substantial debate to take place about the different pathways or alternatives to reform the constitution. Whilst the chosen mechanism involved reforming the constitution and create a legal basis for the constitution - a feature that has been heralded as one of the most promising aspect of the Chilean reform process-this possibility only became clearer after Bachelet's unsuccessful reform attempt and was only made concrete in the November 2019 Congressional Acuerdo por la Paz Social. As has been thoroughly discussed elsewhere in this issue, this agreement clearly expressed that the Constitutional Convention-if approved via plebiscite-would only be in charge of writing a new constitutional text and nothing else, thus allowing the existing branches of power to function normally and without the interference, oversight, intervention or demise in hands of the Constituent Assembly. Subsequently, the Chilean Congress enacted Law 21,200 in December 2019, the purpose of which was to reform Chapter XV of the Constitution of Chile, which entailed the regulation of the process of reform of the Constitution. In fact, the procedure details the steps to be followed in the constitutional process. The constitutional plebiscite was regulated as a mechanism that activates the constituent process; the Constitutional Convention was organised as a constitution-making body, and established mechanisms of participation in the process.

This is not what happened in Venezuela-not because there weren't voices that expressed their preference for different alternatives, but because a particularly unfortunate combination of factors allowed for the country's particular trajectory to take place, enabled Chavismo's authoritarian path to prevail. Nonetheless, the eminently political nature of constituent processes often leads them to overflow the established legal limits, and such a possibility should not be ruled out a priori in the Chilean case.

\section{Concluding Remarks}

Our comparative analysis of Chile and Venezuela identified and discusses key similarities and differences between the historical, socio-political, and institutional contexts, and the early stages of the constitutional redrafting processes in these countries. The analysis stops at the creation of the Convention, a time when our attention would shift to its operation and performance. At the time of writing -2 months into its 9-month term-it is still somewhat early in the Chilean reform process to make a definitive evaluation. The process has already been worthy of praise and recognition in several regards, including the Convención's incorporation of a wide range of representatives and views (as opposed to be subject to or hijacked exclusively by political parties or a key leader); that the electoral processes of October 25, 2020 (plebiscite) and May 15 and 16, 2021 (election of the members of the Constitutional Convention) took place in free and fair terms, without violence and in a spirit of 
civic consensus for change (despite the ongoing COVID 19 pandemic) ${ }^{56}$ that the Convention became an elected citizen assembly with gender parity and representation of indigenous peoples; or that throughout the constitutional change process the level of support for change among Chilean citizens seems to continue, or even increase in recent months. ${ }^{57}$

Yet, there are other aspects that remain uncertain about the process and that require close attention in the coming months, including the November 2021 presidential election and its potential effect on the Convention; ${ }^{58}$ the continuing bursts of street protests in Santiago and other cities across the country and, more importantly, the determinations that the Constitutional Convention itself yet needs to make concerning its regulation and deliberations, including the rules that govern its deliberation, operation and decision-making. ${ }^{59}$ Tensions surrounding the level of political consensus and modalities required to adopt constitutional norms continue, including the possible adoption of a plebiscite to consult voters on matters that receive at least $3 / 5$, but fail to achieve $2 / 3$ of the Convention's representatives support. ${ }^{60}$ Thus, the dynamics of the Convention may still push the boundaries of what was agreed, and make Chile's constitution-making process more challenging and unpredictable. By the time this issue is published we will be in a better position to evaluate these and other important aspects that influence the Convention's dynamics, on the route to Chile's novel democratic constitution.

\section{Funding None.}

Availability of Data and Material Not applicable.

Code Availability Not applicable.

\section{Declarations}

Conflict of Interest The authors declare that they have no competing interests.

\section{References}

Aveledo RG (2001) Sobre los riesgos de reformar la Constitución por medio no establecido en ella (visión del proceso constituyente de 1999). In: Casal JM, Chacón Hanson A (eds) El Nuevo derecho constitucional venezolano. Universidad Católica Andrés Bello, Caracas, pp 31-60

\footnotetext{
56 Figueroa (2021).

57 See Negretto's article in this Special Issue.

58 See https://www.reuters.com/world/americas/uncertainty-reigns-chile-presidential-election-entershome-stretch-2021-08-24/ (Accessed on September 9, 2021).

59 See https://www.pauta.cl/politica/reglamento-convencion-constitucional-normas-funcionamiento (Accessed on September 10, 2021).

60 See https://www.elmostrador.cl/destacado/2021/10/06/con-mas-de-2-3-de-los-votos-convencion-aprue ba-plebiscito-intermedio-dirimente-formula-sujeta-a-reforma-constitucional/ (Accessed on October 7, 2021).
} 
Ayala Corao C, Casal JM (2008) La evolución político-institucional de Venezuela: 1975-2005. Estud Constit 6:435-499

Aylwin J (2019) Proceso constituyente y miedo a la Democracia https://www.ciperchile.cl/2019/12/17/ proceso-constituyente-y-el-miedo-a-la-democracia/. Accessed 2 Sept 2021

Barrientos FS (2014) Asamblea Constituyente: La experiencia Latinoamericana y el actual debate en Chile. Estud Constit 12:397-428

Bejarano AM, Segura R (2008) Reforma constitucional en tiempos de crisis: Lecciones de Colombia y Venezuela. Rev Latinoam Polít Comp 1:155-180

Bejarano AM, Segura R (2020) The difference power diffusion makes: explaining divergent outcomes in Colombia (1990-1991) and Venezuela (1998-1999). In: Negretto G (ed) Redrafting constitutions in democratic regimes: Theoretical and comparative perspectives. Cambridge University Press, Cambridge, pp 131-154

Braver J (2016) Hannah Arendt in Venezuela: The Supreme Court battles Hugo Chávez over the creation of the 1999 constitution. Int J Constit Law 14:555-583

Brewer Carías AR (1998) Cinco siglos de historia y un país en crisis. Academia de Ciencias Políticas y Sociales and Comisión Presidencial V Centenario de Venezuela, Caracas, Venezuela

Brewer Carías AR (2002) Golpe de Estado y proceso constituyente en Venezuela. UNAM, México

Brewer Carías AR (2010) Dismantling democracy in Venezuela: the Chavez authoritarian experiment. Cambridge University Press, New York

Brewer Carías AR (2021) La muerte de una constitución: La experiencia del proceso constituyente de Venezuela de 1999 desencadenado por unas sentencias de la Corte Suprema de Justicia del 19 de enero de 1999. Editorial Jurídica Venezolana, Caracas, Venezuela

Colón Ríos J (2011) Carl Schmitt and constituent power in Latin American courts: The cases of Venezuela and Colombia. Constellations 18:365-388

Colón Ríos J (2020) Constituent power and the law. Oxford University Press, Oxford

Combellas R (1993) Venezuela: crisis política y reforma constitucional. Universidad Central de Venezuela, Caracas

Cuñarro Conde EM (2009) Venezuela 1984-1999: 15 años de historia (La Comisión Presidencial para la Reforma del Estado (COPRE) como mecanismo de innovación política). Cuest Polít 20 (33). https:// produccioncientificaluz.org/index.php/cuestiones/article/view/14388

Figueroa P (2021) Constitutional referendum during the Covid-19 pandemic: the case of Chile. International Institute for Democracy and Electoral Assistance (IDEA), Stockholm. https://www.idea. $\mathrm{int} /$ sites/default/files/constitutional-referendum-during-the-covid-19-pandemic-the-case-of-chile-en. pdf. Accessed 10 Sep 2021

Frente Patriótico (1991) Por una asamblea constituyente para una nueva Venezuela. Caracas, Venezuela

Gabaldón Domínguez A (1992) El movimiento nacional por la constituyente. Revista Centro Gumilla, Mayo, pp 173-175

García JF, Verdugo S (2020) Introduction: Symposium on Chile's constitution-making process. Int J Consti Law Blog. http://www.iconnectblog.com/2020/10/introduction-symposium-on-chiles-constituti on-making-process/. Accessed 15 Aug 2021

Garcia Guadilla MP, Roa E (1996) Gobernabilidad, cambio político y sociedad civil: El proceso constituyente en Venezuela. Rev Venez Econ Cienc Soc 2:85-112

Garcia-Guadilla MP, Hurtado MH (2000) Participation and constitution making in Colombia and Venezuela: enlarging the scope of Democracy? In: Paper presented at the Annual Meeting of the Latin American Studies Association (LASA), Miami, Florida, pp 16-18

Garreton M (2003) Incomplete democracy. University of North Carolina Press, Chapel Hill

Hawkins K (2010) Venezuela's chavismo and populism in comparative perspective. Cambridge University Press, Cambridge

Hernández Muñoz E (2008) Transición en democracia (Venezuela, 1935-1999). Universidad Central de Venezuela, Caracas

Hirschl R (2005) The question of case selection in comparative constitutional law. Am J Comp Law 53:125-156

Hirschl R (2015) Comparative matters: the renaissance of comparative constitutional law. Oxford University Press, Oxford

Hudson A (2021) The veil of participation: Citizens and political parties in constitution-making processes. Cambridge University Press, Cambridge

Keck M, Sikkink K (1998) Activists beyond borders: advocacy networks in international politics. Cornell University Press, Ithaca 
Kornblith M (1991) The Politics of constitution-making: Constitutions and democracy in Venezuela. J Lat Am Stud 23:61-89

Lalander R (2004) Algunas reflexiones sobre populismo, descentralización y chavismo. Provincia 11:36-97

Landau D (2013) Abusive constitutionalism. UC Davis Law Rev 47:1-58

Landau D, Dixon R (2015) Constraining constitutional change. Wake for Law Rev 50:859-890

Levine D (1998) Beyond the exhaustion of the model: survival and transformation of democracy in Venezuela. In: Canache D, Kulisheck MR (eds) Reinventing legitimacy: democracy and political change in Venezuela. Greenwood Press, Westport, pp 187-214

López Maya M (2003) The Venezuelan Caracazo of 1989: Popular protest and institutional weakness. J Lat Am Stud 35:117-137

López Maya M (2018) Populism, 21st century socialism and corruption in Venezuela (2018) Thesis Eleven 149: 67

McCoy J (1999) Chávez and the end of 'Partyarchy' in Venezuela. J Democr 10:64-77

Naím M, Piñango R (1985) El caso Venezuela. Una ilusión de armonía. IESA, Caracas

Negretto GL (2015) Procesos constituyentes y refundación democrática: El caso de Chile en perspectiva comparada. Rev Cienc Polít 35:201-215

Negretto GL (2018) Democratic constitution-making bodies: The perils of a partisan convention. Int J Constit Law 16:254-279

Negretto GL (ed) (2020) Redrafting constitutions in democratic regimes. Cambridge University Press, Cambridge

Penfold-Becerra M (2004) Federalism and institutional change in Venezuela. In: Gibson EL (ed) Federalism and democracy in Latin America. The Johns Hopkins University Press, Baltimore, pp 197-225

Rey JC (2007) Sobre los conceptos de constitución y poder constituyente en el proyecto político de Hugo Chávez. Centro Gumilla (caracas) 697:307-316

Rubinelli L (2020) Constituent power: A history. Cambridge University Press, Cambridge

Sánchez Urribarrí RA (2011) Courts between democracy and hybrid authoritarianism: evidence from the Venezuelan Supreme Court. Law Soc Inq 36:854

Siavelis P (2009) Enclaves de la transición y democracia chilena. Rev Cienc Polít 29:3-21

Ungar M (2002) Elusive reform: democracy and the rule of law in Latin America. Lynne Rienner Publishers

Vega M (2020) Análisis en DW: Cómo el proceso constituyente chileno se diferencia de los demás en Latinoamérica. https://www.biobiochile.cl/noticias/internacional/america-latina/2020/10/23/anali sis-en-dw-como-el-proceso-constituyente-chileno-se-diferencia-de-los-demas-en-latinoamerica. shtml. Accessed 15 Aug 2021

Verdugo S, Contesse J (2018) The rise and fall of a constitutional moment. Lessons from the Chilean experiment and the failure of Bachelet's project, Int'1 J Const L Blog Mar 13, 2018. http://www. iconnectblog.com/2018/03/the-rise-and-fall-of-a-constitutional-moment-lessons-from-the-chileanexperiment-and-the-failure-of-bachelets-project. Accessed 17 Aug 2021

Verdugo S, Prieto Rudolphy M (2021) The dual aversion of Chile's constitution-making process: Bolivarian constitutionalism and the Pinochet constitution. Int'1 J Const L (forthcoming, 19)

Publisher's Note Springer Nature remains neutral with regard to jurisdictional claims in published maps and institutional affiliations. 